\title{
U ŹRÓDEŁ NOWOŻYTNEGO ROZUMIENIA PRAW JEDNOSTKI NA PRZYKŁADZIE KONCEPCJI UPRAWNIEŃ NATURALNYCH THOMASA HOBBESA
}

\begin{abstract}
W artykule podjęto próbę scharakteryzowania kluczowych elementów nowożytnego rozumienia uprawnień jednostki na przykładzie doktryny Thomasa Hobbesa. Pierwsza część pracy stanowi wskazanie konstytutywnych elementów nowożytności, ze szczególnym uwzględnieniem nowożytnego modelu prawa natury. Posłużono się w tej cześci proponowanym, między innymi przez Norberto Bobbio, rozróżnieniem dwóch pojęciowych modeli prawa naturalnego. Wskazano również wpływ kartezjańskiego sposobu postrzegania świata na rozwój doktryny uprawnień naturalnych. Druga część pracy stanowi analizę doktryny uprawnień naturalnych Hobbesa. W części tej omówiono zarówno samo pojęcie uprawnienia naturalnego, jak i sposób pojmowania prawa natury przez angielskiego filozofa. Starano się wykazać, że dorobek myśliciela może zostać uznany za kamień milowy $\mathrm{w}$ procesie zerwania $\mathrm{z}$ arystotelesowską tradycją postrzegania człowieka i świata. Takie twierdzenie zostaje uprawnione między innymi dzięki przeciwstawieniu koncepcji uprawnień naturalnych nakazom prawa natury. Zwrócono również uwagę na proces transformacji omawianych uprawnień w uprawnienia, które mają przysługiwać, wedle Hobbesa, suwerenowi. Mechanizm powstawania społeczności państwowej przedstawiono z perspektywy kartezjanizmu Hobbesa, co pozwoliło na ukazanie owej transformacji przez pryzmat ruchu, będącego jednym $\mathrm{z}$ podstawowych aspektów doktryny myśliciela. W ostatniej części wskazano również, że podstawowe uprawnienia jednostek nie mogą zostać, w doktrynie analizowanego myśliciela, przeniesione i taki sposób ich postrzegania pozwala uznać dorobek Hobbesa za istotny w rozwoju koncepcji fundamentalnych praw przysługujących jednostce.
\end{abstract}

Słowa kluczowe: uprawnienia naturalne, uprawnienia, Thomas Hobbes.

\section{KONSTYTUTYWNE ELEMENTY NOWOŻYTNOŚCI}

Za idee, które ukonstytuowały nowożytną teorię polityki i odcisnęły znaczące pięto na wieku XVI i w początkach XVII, uznaje się takie koncepty jak umowa społeczna, głosowanie większościowe, reprezentacja polityczna, wola powszechna i wreszcie naturalne i polityczne uprawnienia (natural and political subjective-rights). Określenie granicy między nowożytnością a czasami przednowożytnymi jest istotne między innymi ze względu na fakt, że takie rozróżnienie konstatuje ,semantykę społeczeństwa nowożytnego". Jak zauważa Daniele Stasi nowożytnością powszechnie określa się okres,

\footnotetext{
1 Mgr Marcin Merkwa, Katedra Prawa i Administracji, Wydział Zarządzania, Politechnika Rzeszowska, Al. Powstańców Warszawy 6, 35-959 Rzeszów, tel. 1786510 63, e-mail: mmerkwa@prz.edu.pl

${ }^{2}$ D. Stasi, Filozofia porzqdku polityczno-prawnego w nowożytności, Wydawnictwo Uniwersytetu Rzeszowskiego, Rzeszów 2009, s. 59.
} 
w którym kluczową rolę odgrywały odkrycia geograficzne, rozwój nauki czy też zakończenie jedności religijnej i politycznej. Okres przednowożytny, pokrywający się z epoką średniowiecza, cechują podporządkowanie wiedzy objawieniu boskiemu i jedność, mającą swe źródła $\mathrm{w}$ Bogu ${ }^{3}$. W kontekście rozpatrywanego $\mathrm{w}$ tej pracy problemu kluczowe wydaje się wskazanie cezury między średniowieczem a nowożytnością na podstawie rozróżnienia między nowożytnymi ideami prawa naturalnego a konceptami wyrosłymi w ramach myślenia chrześcijańskiego. W takim ujęciu nowożytność jawić się będzie jako oderwanie się różnego rodzaju koncepcji od teologicznej podstawy, zawierającej idee, takie jak prawo natury czy też prawo boskie, zbawienie czy sprawiedliwość boska ${ }^{4}$.

Ciekawy sposób nakreślenia wspomnianej cezury prezentuje Bobbio. Analizując relacje między koncepcją prawa naturalnego a idea państwa, Norberto Bobbio dokonuje rozróżnienia między nowożytnością a średniowieczem, które zasadza się na różnych sposobach określania fundamentów idei prawa naturalnego w tych dwóch epokach. W okresie średniowiecza dominował model określany przez Bobbio jako „arystotelesowski”, zgodnie z którym podstawą każdego społeczeństwa jest rodzina, która stanowi fundament dla większych społeczności, w tym dla doskonałego zrzeszenia, jakim jest polis. Drugi z modeli teorii prawa naturalnego, którego istotę stanowi uznanie dychotomii między stanem natury a cywilizowanym społeczeństwem, zdominował filozofię polityki od Hobbesa, przez Lockea i Kanta, aż do Hegla ${ }^{5}$.

Jak zauważa Bobbio, ów drugi model zasadza się na fundamentalnym rozróżnieniu pomiędzy stanem natury a cywilizowanym społeczeństwem. Kluczowymi elementami dla tej konstrukcji pojęciowej jest, po pierwsze, wspomniany stan przedpaństwowy, będący punktem wyjścia dla wszelkich rozważań o państwie, jego powstaniu i podstawach istnienia. Kolejnym elementem jest przeciwstawienie stanu natury społeczeństwu państwo jako organizacja społeczna jest antytezą stanu naturalnego. Podstawą, choć niewyłączną, stanu natury są poszczególne jednostki, które nawet jeśli nie żyją w społeczeństwie, to jednak są zdolne do procesu socjalizacji (mówiąc o tym, że jednostki nie są wyłączną podstawą stanu natury, Bobbio ma na myśli to, iż w omawianym stanie mogą istnieć naturalne zrzeszenia ludzi, takie jak chociażby rodzina). Stan natury jest ponadto zawsze przedstawiany jako okres wolności i równości, a przejście ludzkości od owego pierwotnego okresu $\mathrm{w}$ społeczeństwo, a więc zorganizowanie państwa, nie jest konieczne. Ten element charakterystyki jest uwypuklony w dziełach takich myślicieli jak Hobbes czy Locke - dobrowolne akty zrzeszenia jednostek, które są wyrazem woli opuszczenia stanu natury, pozwalają uznać społeczeństwo za sztuczny twór, wytwór nie natury, a kultury. Taki sposób określenia powstania organizacji państwowej każe również uznać zgodę za podstawę legitymacji zrzeszenia politycznego ${ }^{6}$.

Wskazanie konstytutywnych elementów nowożytnego modelu nie oznacza, że był to jednolity, powielany przez wszystkich autorów model opisywania organizacji państwowej. Bobbio zwraca uwagę, że w XVII i XVIII w. pojawiło się wiele wariacji

\footnotetext{
${ }^{3}$ Ibidem, s. 69.

${ }^{4}$ From Irenaeus to Grotius: A Sourcebook in Christian Political Thoughts, red. O. O'Donovan, J. Lockwood O'Donovan, Wm. B. Eerdmans Publishing Company, Cambridge 1999, s. 550.

${ }^{5}$ N. Bobbio, Thomas Hobbes and the Natural Law Tradition, The University of Chicago Press, Chicago 1993, s. 1.

${ }^{6}$ Ibidem, s. 2 .
} 
dotyczących zarówno stanu natury, jak i charakteru umowy społecznej. I tak na przykład niektórzy z myślicieli postrzegali ów stan jako fakt historyczny, podczas gdy inni uznawali go jedynie jako użyteczną fikcję, pozwalającą opisać naturę człowieka i sposób powstawania państwa. Ponadto był on postrzegany zarówno jako stan wojny, jak też jako stan pokoju, a jednostki w nim egzystujące jako pozostające bądź to w izolacji, bądź też w przedpaństwowych zrzeszeniach takich jak rodzina. Pactum societatis, a wiec umowa zrzeszająca, nie we wszystkich teoriach była jedyną umową zawieraną przez jednostki. Niektórzy z myślicieli uznawali za konieczne zawarcie jeszcze umowy dodatkowej, pactum subjectionis, zawieranej miedzy ludem a władcą. Ponadto często podnoszony był problem trwałości umowy społecznej, a więc możliwości wypowiedzenia posłuszeństwa panującemu władcy. Niezależnie jednak od tych modyfikacji - zauważa Bobbio - żadna z nich nie powodowała zmiany tych elementów, które uznane zostały za konstytutywne dla omawianego modelu? ${ }^{7}$.

W opozycji do omawianej grupy idei znajduje się model, który można określić jako arystotelesowski. Arystoteles w Polityce, opisując sposób powstania państwa, stwierdza: „,najpierw tedy konieczną jest rzeczą, aby się łączyły ze sobą istoty, które bez siebie istnieć nie mogą, a wiec żeńska i męska w celu płodzenia [...]. Z obu tych wspólnot powstaje tedy najpierw dom, czyli rodzina [...]. Pierwsza wspólnota większej ilości rodzin dla zaspokojenia potrzeb, wychodzących poza dzień bieżący stanowi gminę wiejską [...]. Pełna w końcu wspólnota, stworzona z większej ilości gmin wiejskich, która niejako już osiagnęła kres wszechstronnej samowystarczalności, jest państwem; powstaje ono dla umożliwienia życia, a istnieje, aby życie było dobre" ${ }^{\text {. }}$. Model oparty na założeniu przyjętym przez Arystotelesa utrzymywał się aż do wieku XVII (na przykład Jan Bodin definiował państwo jako sprawiedliwy rząd na wieloma rodzinami ${ }^{9}$ ). Do kluczowych elementów modelu przednowożytnego należy zaliczyć przede wszystkim to, że rozstrzyganie o pochodzeniu państwa rozpoczynało się, pisze Bobbio, od konkretnego, historycznie zdeterminowanego rodzaju społeczności, jakim była rodzina. Ponadto państwo nie zostaje przeciwstawione rodzinie, stanowi jej ciągłość i pewną formę rozwoju. Stan natury nie jest stanem izolacji - to okres, który można określić jako „czas rodzin”. Konsekwencją tego jest również uznanie, że jednostki, nie żyjąc w alienacji, lecz we wspólnotach rodzinnych, od narodzin podlegają władzy, na przykład rodzicielskiej. Powstanie państwa w omawianym modelu nie jest następstwem dobrowolnej umowy, a ekspansji terytorialnej czy wzrostu populacji. Legitymacją władzy nie jest więc zgoda, a konieczność, natura rzeczy ${ }^{10}$.

Porównanie,przytoczonych wcześniej elementów dwóch modeli pozwala wskazać na „wielkie dychotomie charakteryzujące rozwój filozofii polityki do Hegla"11. Sa to: racjonalistyczna lub socjologiczno-historyczna koncepcja państwa, uznanie państwa za antytezę bądź dopełnienie stanu naturalnego, atomistyczno-indywidualistyczna lub organicystyczna koncepcja państwa, wyidealizowana koncepcja stanu natury

\footnotetext{
${ }^{7}$ Ibidem, s. 3-4.

${ }^{8}$ Arystoteles, Polityka, tłum. L. Piotrowicz [w:] Arystoteles, Dzieła wszystkie, t. I, Warszawa 2003, I, 1, 4-8.

9 J. Bodin, Six Books of Commonwealth, tłum. M.J. Tooley, I, I. Tekst dostępny na stronie: http://www.constitution.org/bodin/bodin.txt (data dostępu: 28.10.2014).

${ }^{10}$ N. Bobbio, op. cit., s. 8-9.

${ }^{11}$ Ibidem, s. 9.
} 
(przejawiająca się w istnieniu w nim uprawnień naturalnych) lub realistyczny sposób postrzegania jednostek (jako zawsze żyjących w różnego rodzaju społecznościach, a więc $\mathrm{z}$ natury mających nierówną pozycję). Ponadto różnice związane są $\mathrm{z}$ umownym lub naturalistycznym określeniem podstawy państwa i określeniem legitymacji władzy w umowie lub - w wypadku modelu asystotelesowskiego - naturze rzeczy ${ }^{12}$.

Nowożytne („subiektywne”) rozumienie uprawnień, które przynoszą wieki XVI i XVII, wymagało zerwania $\mathrm{z}$ dorobkiem średniowiecza przede wszystkim $\mathrm{w}$ aspekcie postrzegania jednostki. Tak długo jak jednostka uznawana była za część świata, element pewnej złożoności, a jej znaczenie było mniejsze niż niektórych innych bytów, koncepcja uprawnień naturalnych nie mogła zostać w pełni rozwinięta. Pojawienie się w średniowieczu idei uprawnień naturalnych musiało zostać dopełnione przez oderwanie człowieka od jednolitego porządku moralnego świata i związanego z nim postrzegania natury. Jak zauważa Gary B. Herbert: obie strony jakiegokolwiek przednowożytnego konfliktu mogły być w błędzie, lecz niemożliwa była sytuacja, by obu przysługiwało uprawnienie - istnienie niezależnego od człowieka porządku naturalnego uniemożliwiało wystąpienie konfliktu uprawnień ${ }^{13}$. Konieczne było przekształcenie pojęcia natury, a więc również roli człowieka w świecie, a także odrzucenie zależności tegoż od Boga ${ }^{14}$. Nowa koncepcja natury musiała powstać na gruzach fizyki Arystotelesa, rządzonej takimi zasadami, jak celowość każdego ruchu ${ }^{15}$, na którą atak prowadzony był między innymi w ramach analizy rzutu poziomego i swobodnego spadania. Świat zaczął być redukowany do materii, ale nie tej, która znana była z filozofii Arystotelesa, a takiej, której właściwości mogły zostać wyrażone w języku matematyki. Jakościowe elementy świata już dla Galileusza mają swe źródło w poznaniu zmysłowym. Galileusz, Kartezjusz, Kepler, tworząc podstawy nowego, matematycznego, postrzegania świata, zrywają między innymi z arystotelesowską doktryną ruchu; ruch jest już niezależny od ciała, tak samo „naturalne” jest dla przedmiotu poruszać się, jak być w stanie spoczynku. Nie można jednak postrzegać w kartezjańskiej mechanice bezpośrednich źródeł dla idei uprawnień subiektywnych - uwolnienie myśli europejskiej od autorytetu Arystotelesa miało również takie konsekwencje, które uniemożliwiają odnalezienie w niej podstawy, czy to dla subiektywnych, czy nawet obiektywnych uprawnień: kolor, smak i zapach stały się domeną subiektywnych zmysłów, jak pisze Herbert: „użytecznym złudzeniem umysłu [...]. Kartezjańska natura to miejsce zderzeń, nie konfliktów, oporu, lecz nie przeciwności. Konflikt i ból, znane elementy świata, w którym żyjemy, nie odnajdują się w kartezjańskiej mechanice. Nie mogą być też z niej wyprowadzone. Maszyny dla przykładu nie mogą odczuwać strachu lub pożądania. Mogą podlegać zmianom, lecz nie mogą cierpieć z powodu straty; z pewnością też nie mogą mieć uprawnień naturalnych, które mogłyby być naruszone przez działanie innej cielesnej maszyny"16.

\footnotetext{
${ }^{12}$ Ibidem.

${ }^{13}$ G.B. Herbert, A Philosophical History of Rights, Transaction Publishers, New Brunswick 2002, s. 83.

${ }^{14}$ Ibidem, s. 83

${ }^{15}$ Zobacz szerzej: F. Copleston, Historia filozofii, t. I: Grecja i Rzym, Instytut Wydawniczy PAX, Warszawa 1998, s. 363-375.

${ }^{16}$ G. B. Herbert, op. cit., s. 89
} 


\section{UPRAWNIENIA NATURALNE W DOKTRYNIE THOMASA HOBBESA}

Mimo że kartezjanizm nie stanowił bezpośredniego źródła nowożytnej koncepcji uprawnień naturalnych, to jednak oddziaływał na nią na wiele sposobów, między innymi kształtując postawę filozoficzną takich myślicieli jak Thomas Hobbes. Według Hobbesa naturą rzeczy jest ruch, ciągły i nieskończony - nie jest więc prawdą, jak chciał Kartezjusz, że nie ma znaczenia, czy ciało porusza się, czy też pozostaje w stanie spoczynku. Sposób pojmowania ruchu, materii czy też w ogóle definiowania natury jest istotny dla oceny dorobku Hobbesa, gdyż przekładał się w znaczym stopniu na postrzeganie jednostek ludzkich jako takich, a także relacji, w jakich one pozostawały, zarówno między sobą, jak i z organizacją państwową. Herbert pisze, że ciało, które Hobbes definiował jako „to, co nie zależy od naszego pomyślenia i co wypełnia jakąś część przestrzeni albo co nią ma równą rozciągłość" ${ }^{17}$, może zostać zredukowane do sumy indywidualnych ruchów, z których najmniejszym jest conatus, definiowany w De Corpore następująco: ,tendencją ruchową jest ruch w przestrzeni w czasie mniejszym niż to, co jest dane, czyli wyznaczony bądź to przez wyraźne wskazanie, bądź przez związanie liczby, to znaczy: że jest to ruch w punkcie" ${ }^{\text {- }}$ - „nie ma nic w hobbesowskim wszechświecie, czego nie dotyczy lub co może uciec od tej ciagłej opozycji i konfliktu ruchów" "19. Ten sposób postrzegania ruchu i natury prowadzić musi do konkluzji, że każda rzecz może być przedmiotem odziaływania innej - przedmioty, ,ich istnienie i konkretne cechy współzależą od natury rzeczy, z którymi pozostają w relacjach” ${ }^{20}$ „życie wszak samo nie jest niczym innym niż ruchem i nie może $\mathrm{w}$ nim nie być pożądania czy też obawy, podobnie jak nie może w nim nie być wrażeń zmysłowych"21.

Kluczowym elementem teorii zbudowanej przez Hobbesa było przeciwstawienie nowego sposobu pojmowania człowieka temu, które znane było $\mathrm{z}$ tradycji arystotelesowsko-tomistycznej. W Lewiatanie Hobbes stwierdza, że ,natura uczyniła wszystkich ludzi [...] równymi”" ${ }^{22}$. Naturalna równość wszystkich ludzi jest to również równość nadziei, że każdy może osiągnąć cele, które sobie wyznaczył - dążenie do nich prowadzi do rywalizacji i nieufności, które - obok żądzy sławy - stanowią główne przyczyny konfliktów ${ }^{23}$. W często cytowanym fragmencie Hobbes pisze: ,jest więc oczywiste, że gdy ludzie żyją, nie mając nad sobą mocy, która by ich wszystkich trzymała w strachu, to znajdują się w stanie, który zwie się wojną; i to w stanie takiej wojny, jak gdyby każdy był w wojnie $\mathrm{z}$ każdym innym. Albowiem wojna polega nie tylko na walce czy też na rzeczywistym zmaganiu: czasem wojny jest odcinek czasu, w którym dostatecznie jest wyraźne zdecydowanie na walkę. [...] Natura wojny polega nie na rzeczywistym zmaganiu, lecz na widocznej do tego gotowości w ciągu tego czasu [...]"24. Taki sposób pojmowania człowieka i stanu natury stawia Hobbesa w opozycji do tradycji,

\footnotetext{
${ }^{17}$ T. Hobbes, O ciele, [w:] T. Hobbes, Elementy filozofii, t. I, tłum. Cz. Znamierowski, PWN, Warszawa 1956, VIII, I, s. 118.

${ }^{18}$ Ibidem, XV, II, s. 227-228.

${ }^{19}$ G. B. Herbert, op. cit., s. 92.

${ }^{20}$ Ibidem.

${ }^{21}$ T. Hobbes, Lewiatan czyli materia, forma $i$ władza państwa kościelnego i świeckiego, tłum. Cz. Znamierowski, Fundacja Aletheia, Warszawa 2009, I, VI, 58, s. 177-178.

${ }^{22}$ Ibidem, I, XIII, 1, s. 204.

${ }^{23}$ Ibidem, I, XIII, 6, s. 206.

${ }^{24}$ Ibidem, I, XIII, 8, s. 206-207.
} 
w tym dorobku Grocjusza. Indywidualizm, zauważa Michael Shortall, jawi się jako centralna kategoria pojmowania moralnego i politycznego porządku w teorii Hobbesa ${ }^{25}$. Widoczne jest to przede wszystkim w sposobie definiowania prawa naturalnego $\mathrm{i}$ uprawnień naturalnych. Hobbes pisze, że „UPRAWNIENIEM PRZYRODZONYM, które pisarze nazywają zazwyczaj ius naturale, jest wolność, jaką ma każdy człowiek, używania swej własnej mocy wedle swej własnej woli dla zachowania własnej istoty, to znaczy własnego życia; i co za tym idzie, wolność czynienia wszystkiego, co w swoim własnym sądzie i rozumieniu będzie on uważał za najstosowniejszy środek do tego zachowania"26. Simone Goyard-Fabre nazywa tę definicję programem, filozoficzną deklaracją Hobbesa. Uprawnienie, według badaczki, będąc w doktrynie angielskiego filozofa uprawnieniem naturalnym (ius naturale), ma charakter indywidualny i może być też postrzegane jako źródło jednostkowej woli. Jest wolnością, władzą, a jego celem jest samozachowanie ${ }^{27}$.

Uprawnienie przyrodzone nie ma już źródła w zobowiązaniu do czynienia tego, co słuszne, a w wolności, która jednostkom w stanie natury umożliwia czynić wszystko to, co konieczne dla ochrony życia (w stanie natury człowiek ma uprawnienie do każdej rzeczy, w tym i do ciała drugiego człowieka): ,subiektywny element ius [...] wychodzi na pierwszy plan i uzyskuje prymat nad innymi elementami sprawiedliwości i prawa"28. Wspomniane uprawnienie, które pozwala jednostkom w stanie natury sięgnąć po wszystko, co konieczne do ochrony życia, jeśli nie zostanie ograniczone, uniemożliwia powstanie społeczeństwa - nie jest bowiem możliwe zapewnienie pokoju i bezpieczeństwa, choćby w najmniejszym stopniu. Stąd fundamentalne prawa naturalne, z których pierwsze nakazuje ludziom „dążyć do pokoju, jak dalece tylko ma nadzieję go osiągnąć, a gdy go osiągnąć nie może, wolno mu szukać wszelkich środków i rzeczy dlań korzystnych w wojnie i ich używać" ${ }^{29}$, a drugie - zrezygnować z uprawnienia do wszystkich rzeczy, a więc ograniczyć swoją wolność tak dalece, jak będzie to konieczne dla osiągnięcia pokoju i ochrony samego siebie ${ }^{30}$. Wspomniane, wyrażone w Lewiatanie (Hobbes w swoich dziełach przytaczał niejednorodne listy prawa natury) pierwsze prawo zawiera, jak zauważył już sam filozof, zarówno pierwsze podstawowe prawo natury, a wiec dążenie do pokoju, jak i najbardziej podstawowe uprawnienie przyrodzone: „bronić samego siebie wszelkimi środkami, jakie są możliwe"31. Trzecim prawem natury sformułowanym przez Hobbesa w Lewiatanie jest obowiązek dopełniania zawartych umów; prawo to, bez którego ,umowy [...] są próżne i nie są niczym innym niż pustymi słowami [...] jest źródłem i pierwowzorem SPRAWIEDLIWOŚCI’’32

Mechanizm transformacji praw naturalnych $\mathrm{w}$ uprawnienia przysługujące Lewiatanowi stanowi jeden z kluczowych punktów teorii Hobbesa. Jednostka ludzka,

\footnotetext{
${ }^{25}$ M. Shortall, Human Rights and Moral Reasoning: A Comparative Investigation by Way of Three Theorists and Their Respective Traditions of Enquiry: John Finnis, Ronald Dworkin and Jürgen Habermas, Pontificia Università Gregoriana, Roma 2009, s. 83.

${ }^{26}$ T. Hobbes, Lewiatan, I, XIV, I, s. 210-211.

${ }^{27}$ S. Goyard-Fabre, Metamorphosis of the Idea of Right in Thomas Hobbe's Philosophy, [w:] C. Walton, P.J.Johnson, Hobbes's 'Science of Natural Justice', Martinus Nifhoff Publishers, Dordrecht, Boston, Lancaster, 1987, s. 153 n.

${ }^{28}$ M. Shortall, op. cit., s. 84 .

${ }^{29}$ T. Hobbes, Lewiatan, I, XIV, 4, s. 212.

${ }^{30}$ Ibidem, I, XIV, 4, 5, s. 21-212.

${ }^{31}$ Ibidem, I, XIV, 4, s. 212.

${ }^{32}$ Ibidem, I, XV, 1-2, s. 227.
} 
działając pod dyktatem rozumu, decyduje się ograniczyć swoje uprawnienia, podjąć wszelkie kroki, które będą mogły zapewnić jej bezpieczeństwo. W The Elements of Law Hobbes zauważa, że możliwe są rezygnacja $\mathrm{z}$ uprawnienia lub jego przeniesienie ${ }^{33}$, podobnie rzecz się ma w Lewiatanie, gdzie zrzeczenie się uprawnienia może przyjąć formę rezygnacji lub jego przeniesienia. Jednakże w pierwszym $\mathrm{z}$ tekstów rezygnacja oznacza swoistą deklarację jednostki, że nie będzie czynić tego, do czego jest uprawniona; w Lewiatanie Hobbes przedstawia definicję, którą można by uznać za bardziej „mechanistyczną”. Filozof pisze, że ,ten bowiem, co się uprawnienia zrzeka lub je innemu oddaje, nie daje temu innemu uprawnienia, którego ten ostatni nie miałby przedtem, albowiem z natury nie ma rzeczy, do której każdy człowiek nie miałby uprawnienia. Rezygnując ze swego uprawnienia, człowiek tylko ustępuje z drogi temu drugiemu, iżby ten mógł korzystać ze swego własnego uprawnienia przyrodzonego bez przeszkody z jego strony, lecz nie bez przeszkody ze strony innych ludzi. Tak więc, gdy jeden człowiek zrzeka się swego uprawnienia, to wychodzi na korzyść drugiego tylko to, że zmniejszaja się dla niego przeszkody w korzystaniu z jego własnego przyrodzonego uprawnienia"34. Ograniczenie uprawnień naturalnych, będące faktycznie jedynie „,zejściem z drogi” i podyktowane nakazami prawa naturalnego, nie skutkuje jednak ograniczeniem wolności jednostki w stosunku do innych jednostek - wszystkie jednostki, nakładając ograniczenia, pozostają równe w wolności. Mamy w tym wypadku do czynienia, jak to określa Goyard-Fabre, z równowagą sił, która czyni zadość zasadzie quod tibi fieri non vis, alteri non feceris ${ }^{35}$. Uprawnienia suwerena w państwie Hobbesa, obejmujące między innymi prawo do karania, rozstrzygania sporów, a także stanowienia prawa, są - jak zauważa sam filozof - niemożliwe do oddzielenia od suwerena; nie mogą zostać przekazane i jako oznaka suwerenności pozwalają rozpoznać, kto jest w państwie podmiotem władzy suwerennej ${ }^{36}$. Do powstania Lewiatana prowadzi ,realna jedność wszystkich w jednej i tej samej osobie powstała na mocy ugody każdego człowieka $\mathrm{z}$ każdym innym, tak jak gdyby każdy człowiek powiedział każdemu innemu: «daję upoważnienie i przekazuję moje uprawnienia do rządzenia moją osobą temu oto człowiekowi albo temu zgromadzeniu pod tym oto warunkiem, że i ty przekażesz mu swoje uprawnienia i upoważnisz go do wszystkich jego działań w sposób podobny». Gdy to się stanie, wielość ludzi zjednoczona w jedną osobę nazywa się PAŃSTWEM, po łacinie CIVITAS. I tak powstanie ten wielki LEWIATAN, a raczej (mówiąc z większym szacunkiem ten bóg śmiertelny [...]"37.

Nieograniczona władza suwerena nie oznacza, że w państwie Hobbesa obywatele nie cieszą się wolnością. Wskazane już zostało, że wolność oznacza w doktrynie analizowanego myśliciela brak zewnętrznych przeszkód. Tak pojmowana wolność naturalna nie jest sprzeczna $\mathrm{z}$ determinizmem: brak zewnętrznej przeszkody, a wiec tego, co zakłócić może ruch, daje człowiekowi możliwość działania zgodnie z własną wolą, mimo że pragnienia człowieka, jego skłonności mają swe źródło w określonej przyczynie, która $\mathrm{z}$ kolei uwarunkowana jest w nieprzerwanym łańcuchu przyczyn, a więc są

\footnotetext{
${ }^{33}$ Hobbes, The Elements of Law, I, 15, 3.

${ }^{34}$ T. Hobbes, Lewiatan, I, XVI, 5, s. 213.

${ }^{35}$ S. Goyard-Fabre, Metamorphosis of the Idea of Right in Thomas Hobbe's Philosophy, s. 159.

${ }^{36}$ T. Hobbes, Lewiatan, II, XVIII, 16, s. 268.

${ }^{37}$ Ibidem, II, XVII, 13, s. 258.
} 
konieczne ${ }^{38}$. Pisząc o wolnościach i prawach poddanych, Hobbes wskazuje z jednej strony na obszar, w którym prawo milczy (brak reguły ustalonej przez suwerena pozwala czynić lub nie czynić w zależności od własnego sądu o rzeczach ${ }^{39}$ ), a także na tę sferę, na którą wpływa podstawowe, przysługujące każdemu człowiekowi prawo do samozachowania. Umowa, w której umocowanie ma władza suwerenna, zawarta jest w celu ochrony zdrowia i życia - suweren nie może nakazać człowiekowi, by sam pozbawił się życia, okaleczył czy przyznał do popełnionych zbrodni lub uczestniczyć w wojnie ${ }^{40}$. Nie można się zrzec podstawowego uprawnienia przysługującego ludziom z natury, a więc prawa, by się chronić; konsekwencją tego jest między innymi to, że ,zobowiązanie poddanych w stosunku do suwerena trwa tak długo i nie dłużej, niż trwa moc, dzięki której jest on zdolny ich ochraniać" $" 11$.

\section{ZAKONCZENIE}

Dorobek Hobbesa, zwłaszcza jego teoria uprawnień naturalnych, jest źródłem wielu interpretacji. Wątpliwości budzi samo uprawnienie naturalne przysługujące jednostkom, postrzegane jako źródło chaosu występującego w stanie natury lub wprost przeciwnie jako konieczny element przystosowania jednostki do tego stanu. Nie ma również w literaturze zgody co do tego, czy w doktrynie Hobbesa można mówić o przeciwstawieniu praw naturalnych prawu naturalnemu. Brak również jednoznacznej odpowiedzi na pytanie, czy dorobek myśliciela jest jedynie konsekwencją wcześniejszych przełomów, dokonanych w filozofii Ockhama i Gersona, czy stanowi novum w teorii uprawnień. Niektórzy $\mathrm{z}$ autorów widzą $\mathrm{w}$ doktrynie angielskiego myśliciela jedynie aberrację od głównego nurtu, w jakim rozwijała się teoria praw podmiotowych.

Przedstawiona w artykule doktryna Hobbesa pozwala jednak na uznanie jego dorobku za znaczący element w rozwoju idei praw podmiotowych. Hobbes nie tylko ujął i wyraził wprost tezy poprzednich myślicieli, ale również nadał im kształt, który można określić jako „nowożytny”. Postawił cezurę pomiędzy średniowiecznym sposobem postrzegania jednostki a nowożytnym rozumieniem jej roli w świecie i chociażby z tego względu jego dorobek ma istotne znaczenie w rozwoju uprawnień subiektywnych, a więc także doktryny praw człowieka.

\section{LITERATURA}

[1] Arystoteles, Polityka, tłum. L. Piotrowicz [w:] idem, Dzieła wszystkie, t. I, Warszawa 2003.

[2] Bobbio N., Thomas Hobbes and the Natural Law Tradition, The University of Chicago Press, Chicago 1993.

[3] Bodin J., Six Books of Commonwealth, tłum. M.J. Tooley, I, I, http://www.constitution.org/bodin/bodin.txt.

[4] Copleston F., Historia filozofii, t. I: Grecja i Rzym, Instytut Wydawniczy PAX, Warszawa 1998.

\footnotetext{
${ }^{38}$ Ibidem, II, XXI, 4, s. 296

${ }^{39}$ Ibidem, II, XXI, 18, s. 306.

${ }^{40}$ Ibidem, II, XXI, 16, s. 305.

${ }^{41}$ Ibidem, II, XXI, 21, s. 308.
} 
[5] Goyard-Fabre S., Metamorphosis of the Idea of Right in Thomas Hobbe's Philosophy, [w:] C. Walton, P.J. Johnson, Hobbes's 'Science of Natural Justice', Martinus Nifhoff Publishers, Dordrecht, Boston, Lancaster 1987.

[6] Herbert G.B., A Philosophical History of Rights, Transaction Publishers, New Brunswick 2002.

[7] Hobbes T., Lewiatan czyli materia, forma i władza państwa kościelnego $i$ świeckiego, tłum. Cz. Znamierowski, Fundacja Aletheia, Warszawa 2009.

[8] Hobbes T., O ciele, [w:] idem, Elementy filozofii, t. I, tłum. Cz. Znamierowski, PWN, Warszawa 1956.

[9] From Irenaeus to Grotius: A Sourcebook in Christian Political Thoughts, red. O. O'Donovan, J. Lockwood O'Donovan, Wm. B. Eerdmans Publishing Company, Cambridge 1999.

[10] Shortall M., Human Rights and Moral Reasoning: A Comparative Investigation by Way of Three Theorists and Their Respective Traditions of Enquiry: John Finnis, Ronald Dworkin and Jürgen Habermas, Pontificia Università Gregoriana, Roma 2009.

[11]Stasi D., Filozofia porzqdku polityczno-prawnego w nowożytności, Wydawnictwo Uniwersytetu Rzeszowskiego, Rzeszów 2009.

FOUNDATIONS OF MODERN UNDERSTANDING OF HUMAN RIGHTS ON THE EXAMPLE OF THE THOMAS HOBBES' THEORY OF NATURAL RIGHTS

In the paper the author made an effort to characterize key elements of modern understanding of natural rights on the example of Thomas Hobbes' doctrine. In the first part of the article fundamental features of modern times were indicated and the Conceptual Model of Natural Law was described in particular. In this part the distinction between two models of natural law made, among others, by Norberto Bobbio was used. Moreover, an influence of Cartesian understanding of world on development of natural rights was shown. The second part of the paper consists of an analysis of Hobbes' natural rights doctrine. The notion of subjective right, as well as the way of understanding the natural law by the English philosopher were presented. The author aimed to point out that the Hobbes achievements might be acknowledge as a milestone in a process of breaking off with Aristotle's tradition of perceiving the human and the world. Particular attention was paid to the process of transformation of natural rights into the rights, which, according to Hobbes, are supposed to be appointed to sovereign. The process of developing a state-society was presented from the perspective of Hobbes' Cartesianism and this perspective enabled to present the transformation through the motion that is one of the essential aspect of the Hobbes' doctrine. Finally, it was indicated in the paper that the subjective rights, according to Hobbes, cannot be transferred and such way of their analysis allow to treat the Hobbes achievements as a significant part of development a theory of fundamental rights.

Keywords: natural rights, rights, Thomas Hobbes.

DOI:10.7862/rz.2014.hss.60

Przesłano do redakcji: listopad 2014

Przyjęto do druku: grudzień 2014 